\title{
An Exploration of Reading Strategy Used by ESP Students:
}

\author{
A Self-Report from First-Year Students
}

\author{
Nunung Mardianti* \\ Language Teaching Program \\ Universitas Negeri Malang \\ Malang, Indonesia \\ *nunung.mardianti.1702128@students.um.ac.id
}

\author{
Primardiana Hermilia Wijayanti \\ German Language Education \\ Universitas Negeri Malang \\ Malang, Indonesia \\ primardiana.hermilia.fs@um.ac.id
}

\begin{abstract}
This study was aimed at exploring reading strategy use by first-year non-English department students in Universitas Muhammadiyah Malang. The participants in this study were 50 Governmental Science students who took intensive reading I. In this study, the questionnaire named Survey of Reading Strategy (SORS) was used to investigate reading strategy level and most preferable of reading strategy use. Based on the result of the study, the non-English department students were classified into low reading strategy user. Moreover, the result illustrated that the preferable reading strategy was thinking about what they know to assist them to understand the text under the area of global strategy. Then it was followed by problem-solving strategy; stop time to time and think about what they are reading. Last, supporting strategy is represented by underlining or circling information on the text to help them understand the text.
\end{abstract}

Keywords-reading strategy use, english for specific purposes, Survey of Reading Strategy (SORS)

\section{INTRODUCTION}

With the emergence of new technologies, the 21 st citizens are able to access complete information exists in media or internet [1]. As a result, the unfiltered information cannot be controlled by teachers, publishers or even parents to hinder the students from unnecessary information. The ability to analyze and evaluating information is highly demanded in the workplace. Moreover, the standard performance of reading proficiency requires the students to be able to analyze, relate and criticize within single and across multiple sources of information.

In University level, students are required to comprehend more complex material to apply appropriate background knowledge in various context. Teaching reading generally belongs to reading comprehension due to its purpose, that is improving students' language skills. According to Cahyono and Widiati [2] reading at a higher level requires the students to read a considerable amount of English texts sources beyond the instruction process. In addition, through reading the students are demanded to understand the topic in order to catch ideas, knowledge and information [3,4]. However, the requirements of reading instruction are not easy to fulfill because Indonesian students feel less motivated when they read a passage. Additionally, when students feel uneasy and confused during reading activities, their cognitive performance will be decreased. They will face difficulties, encourage negative value toward themself and finally minimize their self-efficacy. A study conducted Suryanto [5] investigating English reading comprehension problems in Indonesian cultural context. The result showed that one of the factors causing a reading comprehension problem was lack of using reading strategies related to English teaching and learning concern.

Reading comprehension can be increased through suitable teaching method and understanding the insight of reading skills and reading strategies [6]. Moreover, reading strategy is one of the students' factors that supports reading comprehension [3,79]. Moreover, "reading strategies are the comprehension processes that readers use in order to make sense of what they read" [10]. It is characterized as approach, action, and procedures used to improve reading comprehension. By using the appropriate strategy, a student will be more understanding in reading the text and solve the difficulties they face.

Reading strategies include reading aloud, paraphrasing, guessing, re-reading the text, visualizing the information, asking oneself questions, translating, and using a dictionary. Taking an example from study conducted by Zare and Othman [11] investigated reading strategy used by Malaysian ESL learners and its relationship with reading comprehension. The researcher administered reading strategy inventory and a reading comprehension test to 95 students. The result of study showed that Malaysian ESL learners were categorized as high strategy users. Furthermore, the strategies employed had positive correlation with reading comprehension achievement. The study indicates that the use of suitable reading strategy can assist the students to improve their reading comprehension. Furthermore, similar findings was also revealed by a Study conducted by Sari [12] found out that fifth-semester of English Department students belongs to high strategy user. 
In short, based on the previous researches that most of the study involving English department students as the subject if the study. Thus, in the current study, the researcher is inspired to raise similar topic to Non-English department students or ESP students to broaden the data by using SORS questionnaire. Moreover, the ESP students who were invited to this study belong to first year students.

Most of the studies found that students are using a variety of strategies while reading in order to read better. These various strategies may involve skimming, scanning, predicting, general knowledge activation, recognizing synonyms and word families, making inferences, and identifying main ideas. In the same line, Furthermore, Almasi and Susan [13] mention the other reading strategies could be used such as evaluating the content, finding an association between the text and previous knowledge or experience, asking and answering questions relevant to the text, identifying keywords, using the grammatical analysis to determine the various components of the sentence, re-reading, paraphrasing and summarizing. Those kinds of reading strategy obviously can be the useful alternative tool to be used for ESP students such as medical science, engineering, IT, economic and Governmental Science who need to study a new language and focus on reading for content since they do not have enough sufficient time for learning English.

The classification of the strategies provided by Oxford [14] commonly used by language learners involves cognitive, memory, compensation, metacognitive, affective, and social strategies. Later on, Mokhtari and Sheorey [15] developed an instrument on assessing EFL/ESL students' reading strategy named the Survey of Reading Strategy (SORS). The instrument consists of three main categories; Global Reading Strategies (GLOB), Problem Solving Strategies (PROB) and Support Strategies (SUP). GLOB refers to planned techniques used by students to organize their reading. The strategies such as making prediction and analyzing the content of the text are included in this category. PROB means the ways the readers use when dealing with a task attached in the text. The examples of strategies in this category are readjusting the reading speed based on the difficulty of the text and using context. Whereas SUP is related to basic support methods or tools to assist students in comprehending the text such as the use of a dictionary, note-taking and underlining the intended information.

\section{MethodS}

The current study belongs to the quantitative method. The population of this study is all students from non-English department who take Intensive Reading I like one of the compulsory subjects in the ESP Program. Moreover, there was 50 first year of Governmental Science students who participated in this study. Collect the data, Survey of Reading Strategy (SORS) which created by Mokhtari and Sheorey [15] was utilized to investigate reading strategy that the students use when they read English texts. SORS functioned as an instrument to measure the level and frequency of reading strategies that adult EFL students perceived they use while reading academic text written in English.

\section{A. Instrument}

This Likert-scale questionnaire contains 30 close-ended items under three subcategories, namely Global Reading Strategies (GLOB) which means a planned techniques used by students to organize their reading, Problem Solving Strategies (PROB) refers to the ways the readers use when dealing with a task attached in the text, and Support Strategies (SUP) is related to basic support methods or tools to assist students in comprehending the text. Since the subject of study was nonEnglish department students, this questionnaire was translated into Bahasa to avoid students from misunderstanding.

\section{B. The procedure of Data Collection}

The procedure of data collection is illustrated as follows. First, concerning administrative requirements, the researcher asked a recommendation letter from the administration staff at the Graduate program to conduct the researcher in Universitas Muhammadiyah Malang. After getting permission to research UMM, Next, the instruments were distributed to the research subjects December 2019. Before distributing the questionnaire, the participants had been told that their identities would keep confidential. The last step was data analysis.

\section{Data Analysis}

In analyzing the data from SORS, several steps were conducted. First, the researcher checked the completeness of all SORS submitted by learners. Second, the score of each item in the questionnaire was calculated to determine the level of reading strategy the students use and which reading strategy was rated as high frequency. Third, the researcher put the data into tabular form to be easily grouped and analyzed. In classifying the data, three categories (GLOB, PROB and SUP) were used.

\section{RESULTS AND DISCUSSION}

This chapter mainly discussed the result of students' score on the reading strategy use questionnaire. Similar to the previous elaboration, reading strategy use also has three aspects, namely global reading strategy, problem-solving strategy and support strategy. Further elaboration will be presented in the following subchapter.

\section{A. Level of Reading Strategy Use}

The initial data are given in terms of the level of reading strategy use. It is classified into high user, moderate user and low user of reading strategy. The student is stated as a high user if their score on reading strategy questionnaire is around 116 to 149 . It means they are frequently use reading strategy in dealing with English text. In terms of a moderate user of reading strategy, the students in this level obtained score around 92 to 125 . In other words, they sometimes use reading strategy in the reading activity. Last, the students with reading 
strategy score around 57 to 91 belong to the group of low user. It means that they are rarely using reading strategy when interacted with English text. Furthermore, the figure below illustrates the reading strategy use:
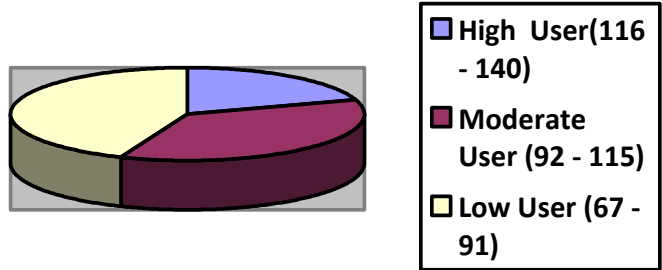

Fig. 1. Level of reading strategy use.

Based on the figure 1 above, most ESP students represented by $44 \%$ of total respondents belong to low reading strategy user. In other words, they rarely use a reading strategy when involving in the reading activity. It can be seen from their reading strategy score that is 67 to 91 . Moreover, $36 \%$ of students are a moderate user. It means they sometimes utilize reading strategy to help them in the reading activity. The reading strategy in this group is ranged from 92 to 115 Nevertheless, $18 \%$ of ESP students belong to high reading strategy user. This group of students belongs to a high user of reading strategy because their reading anxiety score is around 116 to 140 , which mean they often use a reading strategy to help their reading activity process.

\section{B. Global Reading Strategy}

Global reading strategy refers to planned techniques the students use to manage their reading. The strategies involve constructing purposes in mind, previewing the length and organization of the text and using typographical aids, tables, and figures. Based on the results of the questionnaire analysis, the summarized result of the analysis of the respondents' reading anxiety reveal the statistics are presented in Table 1.

TABLE I. GLOBAL READING STRATEGY

\begin{tabular}{|c|c|c|c|c|c|c|c|c|c|c|c|}
\hline \multirow{2}{*}{ No } & \multirow{2}{*}{$\begin{array}{c}\text { Statement } \\
\text { Global Reading Strategy }\end{array}$} & \multicolumn{2}{|c|}{ Never } & \multicolumn{2}{|c|}{ Occasionally } & \multicolumn{2}{|c|}{ Sometimes } & \multicolumn{2}{|c|}{ Usually } & \multicolumn{2}{|c|}{ Always } \\
\hline & & Frequency & Percentage & Frequency & Percentage & Frequency & Percentage & Frequency & Percentage & Frequency & Percentage \\
\hline 1 & I have a purpose in mind when I read. & 5 & $10 \%$ & 4 & $8 \%$ & 22 & $44 \%$ & 6 & $12 \%$ & 13 & $26 \%$ \\
\hline 2 & $\begin{array}{l}\text { I think about what I know to help me } \\
\text { understand what I read. }\end{array}$ & 2 & $4 \%$ & 8 & $16 \%$ & 7 & $14 \%$ & 22 & $44 \%$ & 11 & $22 \%$ \\
\hline 3 & $\begin{array}{l}\text { I take an overall view of the text to } \\
\text { see what it is about before reading it. }\end{array}$ & 4 & $8 \%$ & 7 & $14 \%$ & 18 & $36 \%$ & 16 & $32 \%$ & 5 & $10 \%$ \\
\hline 4 & $\begin{array}{l}\text { I think about whether the content of } \\
\text { the text fits my reading purpose. }\end{array}$ & 4 & $8 \%$ & 12 & $24 \%$ & 12 & $24 \%$ & 14 & $28 \%$ & 8 & $16 \%$ \\
\hline 5 & $\begin{array}{l}\text { I review the text first by noting its } \\
\text { characteristics like length and } \\
\text { organization }\end{array}$ & 4 & $8 \%$ & 11 & $22 \%$ & 16 & $32 \%$ & 10 & $20 \%$ & 9 & $18 \%$ \\
\hline 6 & $\begin{array}{l}\text { I try to get back on track when I lose } \\
\text { concentration. }\end{array}$ & 4 & $8 \%$ & 7 & $14 \%$ & 8 & $16 \%$ & 15 & $30 \%$ & 16 & $32 \%$ \\
\hline 7 & $\begin{array}{l}\text { When reading, I decide what to read } \\
\text { closely and what to ignore. }\end{array}$ & 3 & $6 \%$ & 6 & $12 \%$ & 17 & $34 \%$ & 19 & $38 \%$ & 5 & $10 \%$ \\
\hline 8 & $\begin{array}{l}\text { I use tables, figures and pictures in } \\
\text { the text to increase my understanding. }\end{array}$ & 6 & $12 \%$ & 15 & $30 \%$ & 9 & $18 \%$ & 14 & $28 \%$ & 6 & $12 \%$ \\
\hline 9 & $\begin{array}{l}\text { I use context clues to help me better } \\
\text { understand what I am reading. }\end{array}$ & 4 & $8 \%$ & 13 & $26 \%$ & 14 & $28 \%$ & 12 & $24 \%$ & 7 & $14 \%$ \\
\hline 10 & $\begin{array}{l}\text { I use typographical features like bold } \\
\text { and italics to identify key } \\
\text { information. }\end{array}$ & 7 & $14 \%$ & 14 & $28 \%$ & 12 & $24 \%$ & 11 & $22 \%$ & 6 & $12 \%$ \\
\hline 11 & $\begin{array}{l}\text { I critically analyze and evaluate the } \\
\text { information presented in the text. }\end{array}$ & 2 & $4 \%$ & 15 & $30 \%$ & 21 & $42 \%$ & 6 & $12 \%$ & 6 & $12 \%$ \\
\hline 12 & $\begin{array}{l}\text { I check my understanding when I } \\
\text { come across new information. }\end{array}$ & 3 & $6 \%$ & 7 & $14 \%$ & 15 & $30 \%$ & 17 & $34 \%$ & 8 & $16 \%$ \\
\hline 13 & $\begin{array}{l}\text { I check to see if my guesses about the } \\
\text { text are right or wrong. }\end{array}$ & 3 & $6 \%$ & 10 & $20 \%$ & 20 & $40 \%$ & 12 & $24 \%$ & 5 & $10 \%$ \\
\hline
\end{tabular}

Since the researcher only focused on the item that frequently chosen by the respondent, then there are just a few items elaborated in this part. Based on the table above, $44 \%$ of ESP students usually think about what they know to assist them to understand the text. Moreover, $34 \%$ of students usually decide what to read closely and what to ignore. Also, $32 \%$ of the total respondents always try to get back when they lose concentration. Furthermore, $34 \%$ of the total students usually check their understanding when finding new information. Last, $28 \%$ of ESP students usually think about whether the content of the text fits their reading purpose. Besides, most of the ESP students responded sometimes, occasionally and never to several strategies. $44 \%$ of total students sometimes have a purpose in mind when reading the text. Moreover, $42 \%$ of the students clarified that they sometimes analyze and evaluate the information stated in the text. Furthermore, only $14 \%$ of ESP 
students admitted that they never use typological features like boldface and italics to identify key information.

\section{Problem Solving Strategy}

In this part, the discussion refers to the problem-solving strategy is the second aspect of this part. It is about actions of procedures the students use when working directly with the text. The problem-solving strategy consists of adjusting the duration of reading, guessing the meaning of unknown words, and re-reading the text to improve comprehension. The result of students' responds about the aspect of the problem-solving strategy is given in the following table 2 .

TABLE II. PROBLEM SOLVING STRATEgy

\begin{tabular}{|c|c|c|c|c|c|c|c|c|c|c|c|}
\hline \multirow{2}{*}{ No } & \multirow{2}{*}{$\begin{array}{c}\text { Statement } \\
\text { Problem Solving Strategy } \\
\end{array}$} & \multicolumn{2}{|c|}{ Never } & \multicolumn{2}{|c|}{ Occasionally } & \multicolumn{2}{|c|}{ Sometimes } & \multicolumn{2}{|c|}{ Usually } & \multicolumn{2}{|c|}{ Always } \\
\hline & & Frequency & Percentage & Frequency & Percentage & Frequency & Percentage & Frequency & Percentage & Frequency & Percentage \\
\hline 1 & $\begin{array}{l}\text { I read slowly and carefully to make } \\
\text { sure I understand what I am reading. }\end{array}$ & 2 & $4 \%$ & 12 & $24 \%$ & 11 & $22 \%$ & 12 & $24 \%$ & 13 & $26 \%$ \\
\hline 2 & $\begin{array}{l}\text { When text becomes difficult, I pay } \\
\text { closer attention to what I am } \\
\text { reading. }\end{array}$ & 5 & $10 \%$ & 6 & $12 \%$ & 12 & $24 \%$ & 18 & $36 \%$ & 9 & $18 \%$ \\
\hline 3 & $\begin{array}{l}\text { I stop from time to time and think } \\
\text { about what I am reading. }\end{array}$ & 2 & $4 \%$ & 8 & $16 \%$ & 14 & $28 \%$ & 20 & $40 \%$ & 6 & $12 \%$ \\
\hline 4 & $\begin{array}{l}\text { I try to picture or visualize } \\
\text { information to help remember what I } \\
\text { read. }\end{array}$ & 2 & $4 \%$ & 9 & $18 \%$ & 15 & $30 \%$ & 16 & $32 \%$ & 8 & $16 \%$ \\
\hline 5 & $\begin{array}{l}\text { I try to guess what the content of the } \\
\text { text about when I read. }\end{array}$ & 2 & $4 \%$ & 9 & $18 \%$ & 19 & $38 \%$ & 14 & $28 \%$ & 6 & $12 \%$ \\
\hline 6 & $\begin{array}{l}\text { When text becomes difficult, I re- } \\
\text { read it to increase my understanding. }\end{array}$ & 7 & $14 \%$ & 9 & $18 \%$ & 6 & $12 \%$ & 12 & $24 \%$ & 16 & $32 \%$ \\
\hline 7 & $\begin{array}{l}\text { When I read, I guess the meaning of } \\
\text { unknown words or phrases. }\end{array}$ & 3 & $6 \%$ & 12 & $24 \%$ & 20 & $40 \%$ & 11 & $22 \%$ & 4 & $8 \%$ \\
\hline 8 & $\begin{array}{l}\text { I adjust my reading speed according } \\
\text { to what } I \text { am reading. }\end{array}$ & 1 & $2 \%$ & 8 & $16 \%$ & 15 & $30 \%$ & 19 & $38 \%$ & 7 & $14 \%$ \\
\hline
\end{tabular}

Regarding the problem-solving strategy, $26 \%$ of ESP students always read slowly and carefully to make sure they understand what they are reading. Besides, 36\% of total respondents stated that they usually pay more attention to what they are reading when the text becomes difficult. Moreover, $40 \%$ of students from time to time and think about what they are reading. The table above also shows that $32 \%$ of students usually try to imagine or visualize information to help them remember what they read. Also, 32\% of students always reread the text to increase their understanding when it becomes complicated. Last but not least, $38 \%$ of total students usually adjust their reading speed based on what they are reading.

Unlike the previous elaboration, the infrequent use of reading strategy also shows high responses. Up to $38 \%$ of ESP students sometimes try to guess the content of the text. Moreover, $24 \%$ of the total students rarely read the text carefully and guess the meaning of unknown words. Also, 7\% of students never re-read the text when it becomes problematic.

\section{A. Support Strategy}

As the last aspect under reading strategy use, support strategy refers to the primary support techniques intended to help the students in comprehending the text. Furthermore, this aspect has several statements, such as using a dictionary, taking notes, and underlining or highlighting textual information. The result of students' responses related to support strategy is illustrated in the table 3 below. 
TABLE III. SUPPORT STRATEGY

\begin{tabular}{|c|c|c|c|c|c|c|c|c|c|c|c|}
\hline \multirow{2}{*}{ No } & \multirow{2}{*}{$\begin{array}{c}\text { Statement } \\
\text { Support Strategy }\end{array}$} & \multicolumn{2}{|c|}{ Never } & \multicolumn{2}{|c|}{ Occasionally } & \multicolumn{2}{|c|}{ Sometimes } & \multicolumn{2}{|c|}{ Usually } & \multicolumn{2}{|c|}{ Always } \\
\hline & & Frequency & Percentage & Frequency & Percentage & Frequency & Percentage & Frequency & Percentage & Frequency & Percentage \\
\hline 1 & $\begin{array}{l}\text { I take notes while reading to help } \\
\text { me understand what I read. }\end{array}$ & 2 & $4 \%$ & 14 & $28 \%$ & 9 & $18 \%$ & 15 & $30 \%$ & 10 & $20 \%$ \\
\hline 2 & $\begin{array}{l}\text { When text becomes difficult, I read } \\
\text { aloud to help me understand what I } \\
\text { read. }\end{array}$ & 9 & $18 \%$ & 7 & $14 \%$ & 16 & $32 \%$ & 11 & $22 \%$ & 7 & $14 \%$ \\
\hline 3 & $\begin{array}{l}\text { I underline or circle information in } \\
\text { the text to help me remember it. }\end{array}$ & 1 & $2 \%$ & 8 & $16 \%$ & 9 & $18 \%$ & 20 & $40 \%$ & 12 & $24 \%$ \\
\hline 4 & $\begin{array}{l}\text { I use reference materials (e.g. a } \\
\text { dictionary) to help me understand } \\
\text { what I read. }\end{array}$ & 5 & $10 \%$ & 12 & $24 \%$ & 18 & $36 \%$ & 9 & $18 \%$ & 6 & $12 \%$ \\
\hline 5 & $\begin{array}{l}\text { I paraphrase (restate ideas in my } \\
\text { own words) to better understand } \\
\text { what I read. }\end{array}$ & 5 & $10 \%$ & 7 & $14 \%$ & 10 & $20 \%$ & 16 & $32 \%$ & 12 & $24 \%$ \\
\hline 6 & $\begin{array}{l}\text { I go back and forth in the text to } \\
\text { find relationships among ideas in it. }\end{array}$ & 4 & $8 \%$ & 3 & $6 \%$ & 16 & $32 \%$ & 15 & $30 \%$ & 12 & $24 \%$ \\
\hline 7 & $\begin{array}{l}\text { I ask myself questions I like to have } \\
\text { answered in the text. }\end{array}$ & 4 & $8 \%$ & 25 & $50 \%$ & 6 & $12 \%$ & 8 & $16 \%$ & 7 & $14 \%$ \\
\hline 8 & $\begin{array}{l}\text { When reading, I translate from } \\
\text { English into my native language. }\end{array}$ & 4 & $8 \%$ & 13 & $26 \%$ & 14 & $28 \%$ & 11 & $22 \%$ & 8 & $16 \%$ \\
\hline 9 & $\begin{array}{l}\text { When reading, I think about } \\
\text { information in both English and my } \\
\text { mother tongue. }\end{array}$ & 8 & $16 \%$ & 9 & $18 \%$ & 16 & $32 \%$ & 10 & $20 \%$ & 7 & $14 \%$ \\
\hline
\end{tabular}

In terms of support strategy aspects, $30 \%$ of total respondents stated that they usually take notes while reading to help them understand what they read. Moreover, $40 \%$ of ESP students usually underline or circle the information on the text to assist them in memorizing it. Also, $32 \%$ of students usually do paraphrasing by restating the ideas using their own words in order to help them comprehend they read. Last, $30 \%$ of students usually go back and forth in the text to find relationships among ideas in it.

To sum up, the highest rank about reading strategy use in each aspect are presented as follows. For global reading strategy, the highest percentage was represented by $44 \%$ of ESP students usually think about what they know to assist them to understand the text. In the problem-solving strategy, $40 \%$ of ESP students usually stop time to time and think about what they are reading. Last but not least, in the support strategy, $40 \%$ of ESP students usually underline or circle the information on the text to help them remember it. From the elaboration above, the most frequent reading strategy use by the students was a global reading strategy because it is the highest percentage among the three aspects.

Concerning the research findings of reading strategy use, the ESP students were classified into low strategy user. This finding indicates that students were rarely used reading strategy in the reading activity. A possible explanation behind students' inactive reading strategy use is because of their learning situation where it took place in the gazebo outside the classroom. The use of reading strategy can be distracted by other students' activity near the gazebo since its location is in the park. Moreover, the ESP students involved in this research were first-year students who have limited exposure to reading strategy that makes them unfamiliar with the variation of reading strategy. In contrast, research findings conducted by
Sari [12] found out that students were categorized as high reading strategy users. One of the causes of different result in the recent study can be seen in the level of research subjects involved. The previous research invited the fifth semester, and this current research was participated by first-year students. Furthermore, it also inconsistent with the study by Zare and Othman [11] illustrated that the Malaysian university students were the high user. It is reasonable since English in Malaysia is used as a second language that enables students to have higher exposure to English rather than students in Indonesia, where English is still used as a foreign language.

Specifically, the majority of students stated that they often think about what they know and what they understand about the text. In other words, the students use their background knowledge to understand the academic text. Moreover, Hatami and Asl [16] affirm that the reader explores the text using their prior knowledge and experience composed of preconceptions regarding the use of language in verbal and written form. When the students recognize detailed information in the text, their background knowledge allows them to find the meaning of the text. Moreover, the possible explanation for this finding also can be seen from the students' background. The participant of this study was government science students who owned specific prior knowledge related to the government and politics field. Additionally, their learning material and test specifically design to meet their learning need; therefore, their background knowledge is useful to help them comprehend the text.

Another finding of the current study showed that students tend to make highlight and circle certain information to help them memorizing important information in the text. Since the ESP students in this study were categorized as low reading strategy users and low comprehensive reader, they tend to make use of tools and simple reading namely underlining and 
circling the textual information to support their reading task. As Mokhtari [15] reported that students with low awareness of reading strategy are commonly those who utilize simple support strategy. It is possible since finding textual information requires less effort rather than processing implicit information. Moreover, in line with the current research findings, the result of the study conducted by Amer and Ahmed [17] illustrated that the participants frequently make underline or circle important information in the text.

\section{CONCLUSION}

The result of this study illustrates that non-English department students belong to low reading strategy user. Moreover, most students preferred to utilize their background knowledge in reading English text related to their field. Another finding of the current study showed that students tend to make highlight and circle on certain information to help them memorize it. The utilization of highlighting and circling on specific information are strategies under the area or support strategy.

\section{ACKNOWLEDGMENT}

The authors would like to thank LP2M Universitas Negeri Malang for funding this study. The authors are also sincerely grateful to the anonymous reviewers for their valuable comments to improve the quality of the present study.

\section{REFERENCES}

[1] S.R. Goldman and C.E. Snow, "Adolescent literacy: Development and instruction," in The Oxford handbook of reading, New York, NY, US: Oxford University Press, 2015, pp. 463-478

[2] B.Y. Cahyono and U. Widiati, "The Teaching of EFL Reading in The Indonesian Context: The State of The Art," TEFLIN Journal, vol. 17, no. 1 , pp. 36-58, 2006.

[3] R.N. Dirga and P.H. Wijayati, "How Can Teachers Assess Reading Skills of Generation Z Learners in German Language Class?," presented at the Material Science and Engineering, 2018
[4] N. Bilikozen and A. Akyel, "EFL Reading Comprehension, Individual Differences and Text Difficult," Reading Matrix, vol. 14, no. 2, pp. 263 296, 2014.

[5] Suryanto, "An Investigation On English Reading Comprehension Problems In Indonesian Cultural Contexts," International Conference on Education, Science, Art and Technology, 2017.

[6] R. Sheorey and K. Mokhtari, "Differences In the Metacognitive Awareness of Reading Strategies among Native and Non-Native Readers," System, vol. 29, no. 4, pp. 431-449, Dec. 2001.

[7] B. Ghonsooly and Z. Loghmani, "The Relationship between EFL Learners' Reading Anxiety Levels and Their Metacognitive Reading Strategy Use,” IJL, vol. 4, no. 3, p. pp.326-344, Aug. 2012.

[8] I. Kuru-Gonen, "The relationship between FL reading strategies and FL reading proficiency: A study on Turkish EFL learners," Educ. Res. Rev., vol. 10, no. 24, pp. 2924-2936, Dec. 2015

[9] M. Gurses and E. Bouvet, "Investigating Reading Comprehension and Learning Styles in Relation to Reading Strategies in L2 Reading in a Foreign Language," vol. 28, no. 1, pp. 20-42, 2016.

[10] C. Brantmeier, The Relationship Between Reader's Gender, Passage Content, Comprehension, and Strategy Use in Reading Spanish as a Second Language. Bloomington: Indiana University, 2000.

[11] P. Zare and M. Othman, "The Relationship between Reading Comprehension and Reading Strategy Use among Malaysian ESL Learners," International Journal of Humanities and Social Science, vol. 3, 2013.

[12] W.P. Sari, "The Relationship Between Reading Anxiety and Reading Strategy Used by EFL Student Teachers," Jurnal Pendidikan dan Pengajaran, vol. 4, no. 2, p. December, 2017.

[13] J.F. Almasi and Susan King Fullerton, Teaching Strategi Process in Reading. 2002.

[14] R.L. Oxford, Language Learning Strategies: What Every Teacher Should Know. New York: New bury House Publisher, 1990.

[15] K. Mokhtari and R. Sheorey, "Measuring ESL students' awareness of reading strategies," journal of developmental educatiom, vol. 25, no. 3, 2002

[16] M. Hatami and H.D. Asl, "The Reading Strategies Used by EFL Students: A Case of Iranian Advanced English Language Learners," JLTR, vol. 8, no. 6, p. 1223, Nov. 2017.

[17] A.A. Amer and Thuwabya Ahmed Al-Barwani, "Student teachers' perceived use of online reading strategies," International Journal of Education and Development using Information and Communication Technology, vol. 6, no. 4, pp. 102-113, 2010. 